Gelanggang Olahraga: Jurnal Pendidikan Jasmani dan Olahraga

Volume 2, Nomor 1, Juli-Desember 2018

e-ISSN : 2597-6567

p-ISSN : 2614-607X

DOI : https://doi.org/10.31539/jpjo.v2i1.417

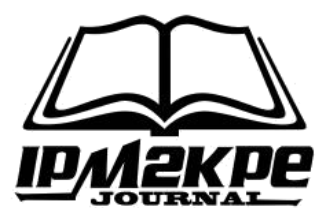

\title{
PENGARUH HIGH INTENSITY INTERVAL TRAINING (HIIT) \\ TERHADAP PERSENTASE LEMAK TUBUH WANITA MENOPAUSE PENDERITA OBESITAS
}

\author{
Muarif Arhas Putra ${ }^{1}$, Rahmi Fitria ${ }^{2}$, Rahmah Evita Putri ${ }^{3}$ \\ Jurusan Pendidikan Olahraga dan Kesehatan ${ }^{1}$, Jurusan Kebidanan, Universitas \\ Pasir Pengaraian ${ }^{2}$, Jurusan Pendidikan IPA,Universitas Negeri Padang ${ }^{3}$ \\ muarifarhasarif@gmail.com ${ }^{1}$
}

\begin{abstract}
ABSTRAK
Tujuan penelitian ini untuk mengetahui pengaruh High Intensity Interval Training (HIIT) terhadap persentase lemak tubuh wanita menopause penderita obesitas. Metode penelitian ini adalah quasi eksperimen. Rancangan penelitian yang dilaksanakan adalah Pretest-Posttest Nonequivalent Control Group Design. Hasil yang didapatkan sebelum dan setelah perlakuan adalah kedua kelompok terdistribusi normal dan homogen. Maka dilaksanakan uji beda dua rata-rata dengan hasil bahwa terdapat perbedaan yang signifikan antara kelompok kontrol dan eksperimen. Simpulan, High Intensity Interval Training (HIIT) memberikan dampak yang signifikan terhadap persentase lemak wanita menopause penderita obesitas.
\end{abstract}

Kata Kunci: HIIT, Obesitas, Menopause.

\section{ABSTRACT}

The purpose of this study was to determine the effect of High Intensity Interval Training (HIIT) on the percentage of body fat in menopausal women with obesity. This research method is a quasi-experimental. The research design carried out was Pretest-Posttest Nonequivalent Control Group Design. The results obtained before and after treatment are the two groups that are normally distributed and homogeneous. Then the two average test was carried out with the result that there were significant differences between the control and experimental groups. Conclusion, High Intensity Interval Training (HIIT) has a significant impact on the fat percentage of menopausal women with obesity.

Keywords: HIIT, Obesity, Menopause.

\section{PENDAHULUAN}

Menopausemerupakan masa haid terakhir pada wanita, yang juga sering diartikan sebagai berakhirnya fungsi reproduksi seorang wanita. Maka, tidak jarang seorang wanita takut menghadapi saat menopausenya. Kehidupan menjelang dan setelah menopause inilah yang sering disebut sebagai 'masa senja'. Sebelum memasuki masa menopause, seorang wanita akan mengalami gejala dan tanda-tanda yang biasa disebut sebagai masa premenopause. Gejala-gelaja menopause dapat menyebabkan ketidaknyamanan dan dampak negatif untuk 
kehidupan wanita yang akan mengalami menopause (Aiello et al, 2007). Gejala negatif tidak hanya berupa ketidaknyamanan secara fisik, namun juga secara psikis.

Pada masa menopause, akan terjadi berbagai perubahan psikis, seperti emosi yang sering meledak, kurangnya percaya diri dan mood yang tidak stabil. Selain itu, akan terjadi juga perubahan secara fisik, seperti kulit yang mulai menegendur dan perubahan berat badan. Sebagian besar wanita yang menderita menopause, akan mengalami kenaikan berat badan akibat hormon esterogen yang berkurang, bahkan tidak lagi diproduksi oleh tubuh. Sedangkan, sebagian besar wanita yang mengalami menopause adalah wanita dengan rentangan usia 40-55 tahun. Dimana, pada usia ini, wanita rentan untuk terkena berbagai macam penyakit. Salah satu penyakit yang mengintai wanita yang terkena menopause adalah penyakit osteoporosis. Wanita yang mengalami menopause pada usia dini 1,83 kali lebih berisiko untuk terkena penyakit osteoporosis pada usia 77 tahun, dan 1,68 ali lebih berisiko untuk mengalami patah tulang (Svejme et al, 2012).

Bertambahnya berat badan, sangatlah berbahaya bagi wanita yang mengalami menopause, karena akan memberatkan kerja sendi dan tulang. Maka, obesitas menjadi musuh utama bagi wanita yang telah mengalami menopause. Selain membahayakan jantung, obesitas juga sangat berbahaya bagi kesehatan sendi dan tulang, karena kadar lemak yang banyak dan menumpuk di dalam tubuh. Namun, pada kenyataannya saat ini, terutama zaman modern dan era praktis, banyak sekali wanita menopause yang terkena obesitas, diakibatkan kurangnya gerak dan pola makan yang sesuai. Kekurangan gerak dan pola makan yang tidak teratur atau sesuai dapat menyebabkan kenaikan berat badan yang signifikan. Akan tetapi hal tersebut dapat dicegah dengan rutin melaksanakan olahraga ringan untuk jantung. Olahraga ringan seperti jalan santai, joging dan senam jantung sehat yang dilaksanakan selama minimal 30 menit.

Hasil observasi awal yang dilaksanakan mengungkapkan bahwa sebagian besar wanita menopause yang mengalami obesitas menyatakan tidak memiliki waktu untuk melaksanakan olahraga. Terutama olahraga seperti joging dan senam jantung sehat, karena pekerjaan. Oleh karena itu, High Intensity Interval Training (HIIT) dapat menjadi salah satu solusi bagi orang-orang yang ingin berolahraga dan menjaga kesehatan tanpa memakan waktu yang banyak. Terutama bagi wanita yang telah menopause, agar dapat sembuh dari mengurangi kadar lemak dalam tubuh. Maka, penelitian ini bertujuan untuk melihat pengaruh HIIT terhadap persentase lemak tubuh wanita menopause penderita obesitas. Tujuan utama dari penelitian ini adalah untuk melihat apakah terdapat pengaruh HIIT terhadap persentase lemak tubuh wanita menopause penderita obesitas.

\section{KAJIAN TEORI \\ Menopause}

Menopause merupakan salah satu tahap kehidupan yang pasti dialami oleh seluruh wanita. Menopause biasanya terjadi pada wanita dengan rentangan usia lebih dari 40 tahun. Pada saat akan mengalami menopause, wanita akan mengalami perubahan secara fisik dan psikis.Gejala-gelaja menopause dapat menyebabkan ketidaknyamanan dan dampak negatif untuk kehidupan wanita yang akan mengalami menopause (Aiello et al, 2007).Wanita yang tidak mengalami siklus mentruasi selama 12 bulan merupakan pertanda bahwa wanita tersebut telah 
memasuki masa menopause dan masa postmenopause dimulai dari masa tersebut (Teoman, 2007).

Menuru Sharma (2008), menopause merupakan risiko berkembangnya penyakit pada kardiovaskular. Jumlah esterogen yang sedikit di dalam tubuh menyebabkan kerugian pada fungsi kardiovaskular dan metabolisme tubuh sehingga massa menopause merupakan faktor risiko berkembangnya penyakit kardiovaskular. Pada usia 40 tahun keatas, kemampuan metabolisme tubuh akan menurun, jika pola hidup ketika masih muda tidak dubah hingga usia 40 tahun, maka akan terjadi penumpukan lemak dalam tubuh. Penumpukan lemak dalam tubuh akan menggiring tubuh pada penyakit-penyakit berbahaya seperi kolesterol dna serangan jantung. Sekitar 135 juta wanita menopause mengalami obesitas $(\mathrm{BMI}>30 \mathrm{~kg} / \mathrm{m} 2)$ di Eropa.

\section{Obesitas}

Obesitas adalah kelebihan lemak dalam tubuh yang umumnya ditimbun dalam jaringan subkutan (bawah kulit), sekitar organ tubuh dan kadang terjadi perluasan ke dalam jaringan organnya (Misnadierly, 2007). Menurut Misnadierly (2007), terjadinya obesitas cendrung ditentukan oleh terlalu banyaknya makan, aktivitas atau latihan fisik yang terlalu sedikit, dan bisa ditentukan oleh kedua faktor tersebut.Sesuai dengan pemaparan oleh Misnadierly (2007), dapat disimpulkan bahwa lemak dalam tubuh yang ditimbun dalam jaringan subkutan diakibatkan oleh terlalu banyak makan dengan disertai aktivitas fisik yang sedikit.

Berdasarkan data WHO, terdapat 1,6 miliar orang dewasa yang memiliki berat badan berlebih (overweight) dan 400 juta diantaranya mengalami obesitas atau kegemukan. Menurut data dari American Heart Association (AHA) pada tahun 2011, terdapat 12 juta (16,3\%) anak di Amerika yang berumur 2-19 tahun sebagai penyandang obese (AHA, 2011). Sekitar satu pertiga $(32,9 \%)$ atau 72 juta orang dewasa warga negara Amerika Serikat adalah obese. Sedangkan di Indonesia, menurut data Riset Kesehatan Dasar (Riskesdas) pada tahun 2007, prevalensi nasional obesitas umum pada penduduk berusia $\geq 15$ tahun adalah 10,3\% (laki-laki 13,9\%, perempuan 23,8\%),

Komposisi lemak dalam tubuh memperlihatkan keseimbangan antara asupan dan penggunaan zat gizi dalam tubuh. Pada saat asupan zat gizi dalam tubuh lebih banyak jika dibandingkan dengan penggunaannya maka kelebihan zat gizi (karbohidrat dan protein) akan disimpan dalam tubuh berupa lemak cadangan. Lemak cadangan dapat terdistribusi di jaringan bawah kulit sebagai lemak subkutan dan area-area visceral yang terdapat dalam rongga dada dan rongga perut sebagai lemak. Penumpukan lemak cadangan secara terus-menerus diikuti dengan aktifitas fisik yang berkurang, akan menjadi penyebab bertambahnya berat badan. Menurut fungsinya, lemak dalam tubuh dibagi menjadi dua bagian, yakni lemak esensial dan lemak non esensial. Lemak esensial merupakan lemak yang dibutuhkan oleh jaringan tubuh seperti pada jantung, memran sel, sumsum tulang dan otak.

\section{High Intensity Interval Training (HIIT)}

High Intensity Interval Training (HIIT) merupakan sebuah pola latihan fisik yang berbasis perulangan (interval training) yang keseluruhan bagian latihannya memiliki intensitas yang tinggi. Menurut Kravitz (2014) periode 
intensif atau sesi HIIT berlangsung sekitar 5 hingga 8 menit, dan membuat jantung berdetak $80 \%$ hingga $95 \%$ dari batas maksimum irama jantung yang merupakan batas detakan jantung maksimum seseorang tanpa harus bergeak secara berlebihan.

Menurut Ross \& Leveritt (2001) HIIT berbeda jika dibandingkan dengan latihan kekuatang (strength), dalam pelatihan kekuatan (strenght training) waktu yang dibutuhkan singkat dan pelatihan yang dilakukan adalah untuk meningkatkan massa otot, HIIT lebih cendrung kepada kegiatan seperti bersepeda dan lari santai. Salah satu strategi HIIT dalam sesi olahraga adalah rentang waktu dalam satu sesi dan sesi tersebut diulang dalam waktu yang konstan.

HIIT menjadi salah satu olahraga yang sangat efektif dan efesien untuk diterapkan pada zaman serba instan seperti saat sekarang. Saat ini di negaranegara maju, sebagian besar orang tidak memiliki waktu untuk berolahraga. Selain tidak memiliki waktu, sebagian besar juga tidak memiliki sempat untuk berolahraga gym ataupun gelanggang olahraga.

HIIT tidak membutuhkan interval waktu yang panjang, bahkan hanya dengan 7 menit, olahraga HIIT sudah dapat dilaksanakan dengan efektif. HIIT juga tidak perlu dilaksanakan ditempat khusus seperti gym ataupun gelanggang olahraga. HIIT dapat dilaksanakan di rumah ataupun di taman disekitar rumah. Oleh karena itu HIIT sangat sesuai untuk negara-negara maju dan negara-negara berkembang yang sangat menghargai waktu. HIIT juga sangat efektif jika diterapkan pada orang lanjut usia, seperti wanita pada masa postmenopause. Berjalan cepat dan diselingi dengan berjalan lamban merupakan olahraga yang efektif untuk wanita menopause, yang jika rutin dilakukan akan membantu menambah kekuatan dan massa otot sekaligus membakar lemak dalam tubuh.

\section{METODE PENELITIAN}

\section{Desain Penelitian}

Rancangan penelitian yang digunakan adalah Pretest-Postest Nonequivalent Control Group Design. Pada desain penelitian ini kadar lemak dalam tubuh terlebih dahulu akan diukur sebelum diberikan HIIT. Selanjutnya diberikan perlakuan selama 5 bulan. Setelah diberikan perlakuan, massa otot dan kadar lemak dalam tubuh kembali diukur.

Tabel 1

Desain Penelitian

\begin{tabular}{llll}
\hline Kelompok HIIT & $\mathrm{O}$ & $\mathrm{X}$ & $\mathrm{O}$ \\
\hline Kelompok kardio & $\mathrm{O}$ & $\mathrm{C}$ & $\mathrm{O}$ \\
\hline
\end{tabular}

Metode penelitian ini adalah penelitian quasi eksperimen. Untuk melihat perubahan persentase lemak tubuh wanita menopause penderita obsitas dengan menggunakan metode latihan High Intensity Interval Training (HIIT). Data yang didapatkan akan diolah secara kuantitatif untuk melihat keefektifan latihan High Intensity Interval Training (HIIT) pada wanita menopause penderita obesitas. 


\section{Populasi dan Sampel}

Populasi penelitian adalah perempuan-perempuan penderita obesitas di Kota Padang dengan rentangan usia 50-60 tahun. Sampel pada penelitian ini diambil sebanyak 50 orang dan dibagi menjadi dua kelompok yakni kelompok eksperimen dan kelompok kontrol. Penelitian dilaksanakan selama 6 bulan dan dilaksanakan di Gelanggang Olahraga Kota Padang.

\section{Prosedur Penelitian}

Untuk mencapai target maksimal pada penelitian ini, maka tahap-tahap penelitian akan dimulai dengan observasi terlebih dahulu. Observasi dilaksanakan untuk mengetahui secara lebih seksama permasalahan dilapangan. Setelah dilaksanakan observasi didapatkanlah beberapa masalah utama yang terjadi dan timbul akibat berat badan berlebih pada wanita dengan kelompok usia 40-60 tahun. Selanjutnya rangkaian permasalahan tersebut diseleksi untuk mencetuskan masalah yang akan diangkat pada penelitian dan terakhir merumuskan masalah.

Seteleh dirumuskannya masalah selanjutnya teori yang sesuai mulai dikaji dengan menggunakan buku sumber dan jurnal-jurnal terbaru. Kemudian hipotesis dirumuskan dan dilaksanakanlah uji hipotesis berupa penetapan variable penelitian, instrumen, populasi dan sampling. Selanjutnya peneliti melakukan pengumpulan data sesuai instrumen yang ada dan pengolahan setelah data diperoleh. Terakhir yakni melaksanakan penarikan kesimpulan berdasarkan data yang telah dibuat.

\section{HASIL PENELITIAN}

\section{Uji Normalitas dan Homogenitas Sebelum Perlakuan}

Sebelum diberikan perlakuan, maka terlebih dahulu dilakukan uji normalitas dan uji homogenitas untuk melihat apakah sampel terdistribusi secara normal dan memiliki varians yang homogen. Hasil uji normalitas kelompok eksperimen dapat dilihat pada Tabel 2.

Tabel 2.

Hasil Uji Normalitas Kelompok Eksperimen Sebelum Perlakuan

\begin{tabular}{cc}
\hline Statistik & Var I \\
N Sampel & 25 \\
\hline Mean & 41,108 \\
\hline Simpangan Baku & 4,120 \\
\hline $\mathrm{D}_{\mathrm{n}}=$ & 0,255 \\
\hline KS Tabel & 0,272 \\
\hline \multicolumn{2}{c}{ Normal } \\
\hline
\end{tabular}

Berdasarkan hasil uji normalitas kelompok eksperimen sebelum diberikan perlakuan, terlihat bahwa kelas kontrol terdistribusi secara normal. 
Tabel 3

Hasil Uji Normalitas Kelompok Kontrol Sebelum Perlakuan

\begin{tabular}{cc} 
Statistik & Var I \\
N Sampel & 25 \\
\hline Mean & 42,925 \\
\hline Simpangan Baku & 5,578 \\
\hline $\mathrm{D}_{\mathrm{n}}=$ & 0,260 \\
\hline KS Tabel & 0,272 \\
\hline \multicolumn{2}{c}{ Normal } \\
\hline
\end{tabular}

normal.

Pada Tabel 3, terlihat bahwa kelompok kontrol memiliki distribusi

Tabel 4.

Hasil Uji Homogenitas Kedua Kelas Sampel

\begin{tabular}{ccccc} 
Var Exp & Var kon & Fh & Ft & Kesimpulan \\
\hline 22,47 & 31,11 & 1,38 & 1,98 & homogen \\
\hline
\end{tabular}

Pada Tabel 4, terlihat bahwa kedua kelas sampel memiliki variansi yang homogen.

\section{Uji Normalitas dan Homogenitas Setelah Perlakuan}

Selanjutnya dilakukan Uji normalitas pada kedua kelompok untuk melihat apakah kedua kelompok terdistribusi secara normal dan homogen, hasil uji normalitas kelompok kontrol setelah diberikan perlakuan dapat dilihat pada tabel 5.

Tabel 5.

Hasil Uji Normalitas Kelompok Kontrol Setelah Diberikan Perlakuan

\begin{tabular}{cc} 
Statistik & Var I \\
N Sampel & 25 \\
\hline Mean & 40,537 \\
\hline Simpangan Baku & 4,879 \\
\hline $\mathrm{D}_{\mathrm{n}}=$ & 0,260 \\
\hline KS Tabel & 0,272 \\
\hline \multicolumn{2}{c}{ Normal } \\
\hline
\end{tabular}

Berdasarkan hasil uji normalitas, pada kelompok kontrol terlihat bahwa kelompok kontrol terdistribusi normal 
Tabel 6

Hasil Uji Normalitas Kelompok Eksperimen Setelah Diberikan Perlakuan

\begin{tabular}{cc} 
Statistik & Var I \\
\hline N Sampel & 25 \\
\hline Mean & 35,328 \\
\hline Simpangan Baku & 2,906 \\
\hline $\mathrm{D}_{\mathrm{n}}=$ & 0,245 \\
\hline KS Tabel & 0,272 \\
\hline \multicolumn{2}{c}{ Normal } \\
\hline
\end{tabular}

Berdasarkan hasil uji normalitas, pada kelompok eksperimen terlihat bahwa kelompok eksperimen terdistribusi secara normal.

Tabel 7.

Hasil Uji Homogenitas

\begin{tabular}{ccccc} 
Var Exp & Var kon & Fh & Ft & Kesimpulan \\
\hline 8,44 & 16,42 & 1,94 & 1,98 & homogen \\
\hline
\end{tabular}

Pada Tabel 7 terlihat bahwa kedua kelompok sampel memiliki variansi yang homoogen.

\section{Uji Rata-rata Dua Arah}

Tabel 8

Uji Rata-Rata Dua Arah

\begin{tabular}{lll}
\hline & Variable & Variable \\
& 1 & 2 \\
\hline Mean & 35,33 & 40,54 \\
\hline Variance & 8,44 & 23,80 \\
\hline Observations & 25,00 & 25,00 \\
\hline Pearson Correlation & 0,90 & \\
\hline $\begin{array}{l}\text { Hypothesized } \\
\text { Difference }\end{array}$ & 0,00 & \\
\hline Df & 24,00 & \\
\hline $\mathrm{t}$ Stat & $-10,06$ & \\
\hline $\mathrm{P}(\mathrm{T}<=\mathrm{t})$ one-tail & 0,00 & \\
\hline $\mathrm{t}$ Critical one-tail & 1,71 \\
\hline $\mathrm{P}(\mathrm{T}<=\mathrm{t})$ two-tail & 0,00 \\
\hline $\mathrm{t}$ Critical two-tail & 2,06 \\
\hline
\end{tabular}

Berdasarkan tabel 8, dapat disimpulakan bahwa Ho Ditolak, karena t hitung yang didapatkan adalah -10,06 dan 10,06. Selanjutnya, t tabel adalah 2,06 
dan -2,06. Karena t hitung <-2,06 dan t hitung > 2,06, maka dapat disimpulkan bahwa kedua sample berbeda secara signifikan.

\section{PEMBAHASAN}

Berdasarkan hasil penelitian yang didapatkan, terlihat bahwa terdapat perbedaan yang signifikan antara kelompok eksperimen dan kelompok kontrol, dimana kelompok eksperimen diberikan perlakuan berupa HIIT, terlihat bahwa dengan memberikan perlakuan HIIT persentase lemak dalam tubuh menurun lebih banyak jika dibandingkan dengan kelompok kontrol yang hanya diberikan perlakuan berupa kardio biasa.

Hal ini dikarenakan HIIT, memberikan intensitas latihan yang lebih tinggi meskipun dengan rentangan waktu yang lebih singkat. Sehingga pembakaran lemak lebih efektif jika dibandingkan dengan kardio biasa. HIIT dapat dilaksanakan di rumah ataupun di taman disekitar rumah. Oleh karena itu HIIT sangat sesuai untuk negara-negara maju dan negara-negara berkembang yang sangat menghargai waktu.

HIIT juga sangat efektif jika diterapkan pada orang lanjut usia, seperti wanita pada masa postmenopause. Berjalan cepat dan diselingi dengan berjalan lamban merupakan olahraga yang efektif untuk wanita menopause, yang jika rutin dilakukan akan membantu menambah kekuatan dan massa otot sekaligus membakar lemak dalam tubuh.

Masa menopause terjadi perubahan kelenjar yang dapat membuat sebagian wanita mengalami pertambahan berat badan. Penyebab yang lazim adalah asupan makanan dan minuman melebihi yang dibutuhkan. Wanita membakar kalori lebih lambat dibandingkan pria, dan tenaga semakin menurun dengan bertambahnya usia. Rasa letih yang biasanya dialami pada masa menopause, diperburuk dengan pola makan yang tidak teratur dan kurang berolahraga.

Aktifitas fisik yang baik memiliki efek positif terhadap kepadatan mineral tulang lebih tinggi dibandingkan pada aktifitas yang ringan. Melakukan aktifitas fisik pada wanita pascamenopause dapat menentukan lajunya kehilangan massa tulang berkaitan dengan usia. Resiko fraktur panggul dapat berkurang dengan olahraga teratur, walaupun densitas mineral tulang karena kekuatan otot, keseimbangan, dan aktifitas .

Jika dibandingkan dengan latihan kardio standar pada umunya, HIIT lebih efektif membakar lemak tubuh. Sedangkan latihan kardio bertujuan untuk melatih gerakan jantung, sehingga tidak signifikan dalam menurunkan kadar lemak dalam tubuh. Berbeda dengan HIIT yang dapat menurunkan kadar lemak dalam tubuh dan melatih gerakan jantung.

\section{SIMPULAN}

Berdasarkan penelitian yang telah dilakukan dapat disimpulkan bahwa terdapat perbedaan yang signifikan antara kelompok yang ekperimen dan kelompok kontrol. Dapat disimpulkan bahwa HIIT memberikan dampak yang signifikan terhadap persentase lemak wanita menopause penderita obesitas. 


\section{DAFTAR PUSTAKA}

Aiello. (2007). Homocysteine, B vitamins, and the incidence of dementia and cognitive impairment: results from the Sacramento Area Latino Study on Aging, American Society for Clinical Nutrition (AJCN), 85 (2), 511-517.

Kravitz, L.(2014).Metabolic Effects of HIIT, Interior Design Educators Association (IDEA), 11, (5).

Misnadierly (2007), Obesitas Sebagai Faktor Resiko Berbagai penyakit, Jakarta. Pustaka Obor Populer.

Ross, A \& Leveritt, M. (2001).Long-Term Metabolic and Skeletal Muscle Adaptations to Short-Sprint Training, 31, (15), 1063-1082.

Sharma, T. (2008). Knowledge of diabetes and diabetic retinopathy among rural populations in India, and the influence of knowledge of diabetic retinopathy on attitude and practice, Rural and Remote Health Education, $838,(8), 1-9$.

Svejme, O. (2012), Early menopause and risk of osteoporosis, fracture and mortality: a 34-year prospective observational study in 390 women, International Journal of Obetetrics and Gynaecology, 119 (7), 810-816.

Teoman, N. (2007) Influences of Acute and Chronic Aerobic Exercise on the Plasma Homocysteine Level. Analisys of Nutrition and Metabolism, 51, 53-58. 